\title{
ESPACIALIZAÇÃO E SENTIDO EM "INTIMIDADE", DE EdLA VAN STEEN: UMA ANÁLISE SEMIÓTICA
}

\section{Ernani Terra* Jessyca Pacheco**}

Resumo: Neste artigo discute-se a espacialização no conto "Intimidade", de Edla Van Steen. O objetivo é mostrar de que modo a espacialização é constitutiva do sentido nesse texto, já que o espaço é tematizado como locus privilegiado da intimidade dos sujeitos. A fundamentação teórica é a semiótica de linha francesa. Como o espaço põe em cena o sujeito, adotou-se também a perspectiva da tensividade. Os resultados obtidos mostram que as transformações do sujeito estão relacionadas a deslocamentos espaciais e que a mudança topológica, na perspectiva da tensividade, leva a uma distensão, já que os sujeitos vão de um espaço tenso e disfórico para um espaço distenso e eufórico.

Palavras-chave: Espacialização. Sentido. Semiótica.

\section{CONSIDERAÇÕES INICIAIS}

"N este artigo, debruçamo-nos sobre o conto "Intimidade", de Edla Van Steen, a fim de verificar como a espacialização opera no sentido de trazer para o componente discursivo axiologias presentes na estrutura profunda, assumidas por sujeitos na estrutura narrativa. Para tanto, fomos obrigados a retomar os estudos da sintaxe discursiva e, particularmente, a forma pela qual o espaço é instalado na narrativa. Ressaltamos que a opção por trabalhar com a categoria espaço deveu-se também ao fato de esta ser, das categorias da enunciação, a menos estudada.

\footnotetext{
* Universidade Presbiteriana Mackenzie (UPM) - São Paulo - SP - Brasil. E-mail: ernani@uol.com.br
}

** Faculdade Metropolitanas Unidas (FMU) - São Paulo - SP - Brasil. E-mail: jezz.pacheco@gmail.com 
Apoiados em Bachelard (2008), pretendemos realizar o que o filósofo francês chama de topoanálise, na medida em que procuramos relacionar os lugares com a vida íntima dos sujeitos. Em A poética do espaço, Bachelard (2008) dedica especial atenção ao espaço casa, considerada por ele um ser privilegiado para o estudo dos valores de intimidade do espaço interior, relacionando espaços da casa a temas.

O espaço pode ser segmentado, apresentando descontinuidades expressas por oposições como / alto vs. baixo/, /dentro vs. fora/. É nessa descontinuidade espacial, particularmente no tratamento da oposição / superatividade vs. inferatividade/, que trabalhamos a fim de mostrar como os sentidos do conto se constroem. Levamos ainda em conta que as tensões se constituem no espaço e que os sujeitos estão mais, ou menos adaptados ao espaço em que transitam, daí as categorias tímicas euforia ${ }^{1}$, termo positivo, e disforia, termo negativo. Em "Intimidade", os sujeitos realizam no espaço um percurso ascendente: vão de baixo (a sala) para cima (o quarto); e isso se constrói no conto como um caráter euforizante.

"Intimidade" foi publicado pela primeira vez em 1984 pela Editora Record, em O prazer é todo meu - contos eróticos femininos, e foi incluído por Italo Moriconi na antologia Os cem melhores contos brasileiros do século. Narra a história de Ema, que recebe em sua casa a amiga Bárbara. Estão sozinhas na sala, quando o rompimento da alça do sutiã de Ema desencadeia uma relação mais intima entre as amigas que se deslocam para o andar superior da casa, onde está o quarto e ali há uma aproximação maior entre elas com a manifestação de desejos de natureza erótica.

\section{Fundamentação TEÓRICA}

A semiótica discursiva francesa tem por objeto de estudo o texto. No dizer de Barros (2003, p. 7), "procura descrever e explicar o que o texto diz e como ele faz para dizer o que diz". Sua preocupação é com o sentido do texto, o que faz que, num primeiro momento, abstraia o plano da expressão, centrando sua análise no plano do conteúdo. Há, evidentemente, textos em que o plano da expressão produz sentido, pensamos naqueles que fazem uso do sistema semissimbólico. Uma das vantagens dessa metodologia é o fato de a análise semiótica poder ser aplicada a qualquer texto, independentemente da expressão que assuma, seja uma pintura, seja um filme, uma peça teatral, um anúncio publicitário ou, como é o caso do que se investiga neste artigo, um texto literário. Para a semiótica, texto é uma unidade de sentido e um objeto de comunicação entre sujeitos, portanto um objeto cultural que manifesta os valores ideológicos de uma dada sociedade.

A semiótica discursiva, segundo Barros (1988, p. 13), "tenta determinar as condições em que um objeto se torna objeto significante para o homem" e, na esteira de Saussure e Hjelmslev, "não toma a linguagem como um sistema de signos, mas como um sistema de significações, ou melhor, de relações, pois a significação decorre da relação" (BARROS, 1988, p. 13).

Para Tatit (2001, p. 100), na euforia há tendência à noção de continuidade, enquanto na disforia a tendência é para a suspensão da continuidade. O autor afirma ainda que "é considerado eufórico, em princípio, tudo que leva à junção com valores desejados e, portanto, à neutralização das tensões". 


\section{O espaço}

Como salientamos, o espaço é a menos estudada das categorias da enunciação. Os estudos literários voltados a essa categoria são realizados na perspectiva de uma semântica espacial, desprezando o componente sintático. Enquanto sujeito e tempo estão sempre marcados na língua por morfemas gramaticais, isso não ocorre com o espaço, que é marcado por morfemas livres, podendo até estar ausente dos textos. Lembremos as palavras de Fiorin (2001, p. 258): "Parece que a linguagem valoriza mais a localização temporal que a espacial, pois podemos falar sem dar nenhuma indicação espacial, quer em relação ao enunciador, quer em relação a um ponto de referência inscrito no enunciado".

Para a semiótica, o espaço é um objeto construído que comporta elementos descontínuos. A debreagem instala a categoria de pessoa (ego) e as coordenadas espácio-temporais (hic e nunc). Espaço e tempo podem corresponder ou não ao momento da enunciação. O sujeito da enunciação, desdobrado em enunciador e enunciatário, cria a partir do ego um eixo de coordenadas espácio-temporais que podem ser ou não coincidentes com o momento e o espaço da enunciação. Dessa forma, temos duas ordens de espaço e de tempo: a do aqui e a do agora que se opõe a do alhures e a do então, respectivamente. Quando espaço e tempo fazem referência à enunciação, temos debreagem espacial e temporal enunciativas. Quando não fazem, temos debreagem espacial e temporal enuncivas.

No tempo, o agora é o marco de referência; na categoria espaço, a referência é o aqui. Para Fiorin (2001, p. 262),

[...] o espaço linguístico ordena-se a partir do hic, ou seja, do lugar do ego. Todos os objetos são assim localizados, sem que tenha importância seu lugar no mundo, pois aquele que os situa se coloca como centro e ponto de referência da localização.

Fixemo-nos na categoria espaço. No discurso, o espaço se organiza a partir do aqui (espaço da enunciação) que se opõe ao espaço fora da enunciação (o alhures). Dessa forma, temos duas ordens de espaço: o enunciativo (espaço do aqui) e o enuncivo (espaço do não aqui). Os efeitos de sentido serão, respectivamente, os de proximidade e de distanciamento da enunciação. Fiorin (2001, p. 259), apoiado em Vernant, afirma que o espaço articula-se "em torno de categorias como interioridade vs. exterioridade, fechamento vs. abertura, fixidez vs. mobilidade, que são homólogas à categoria feminilidade vs. masculinidade", na cosmologia grega. O espaço aparece divido em camadas, sendo a superior a dos deuses, a do meio a dos homens e a inferior da morte e dos deuses subterrâneos. A citação de Fiorin (2001) aplica-se ao conto objeto de análise deste artigo, particularmente à categoria /interioridade vs. exterioridade/, pois no conto o interior é o espaço feminino por excelência. É nesse espaço que Ema e Bárbara se deslocam, enquanto os maridos estão no espaço exterior.

Acrescentamos que, relacionadas à espacialização dos seres no discurso, temos também categorias como / proximidade versus afastamento/ (relativas a distância), /verticalidade versus horizontalidade/ (relativas a direcionalidade) e /englobado versus englobante/ (relativas a abrangência). 
Em "Intimidade", a casa de Ema é o espaço englobante em que se inserem os programas narrativos dos sujeitos: a sala e o quarto, espaços englobados. $\mathrm{Na}$ relação entre casa e rua, esta é englobante e aquela, englobada. Podemos afirmar que, no deslocamento de um espaço para o outro, opera-se a principal transformação dos sujeitos.

A casa, como espaço doméstico, é "um corpo de imagens que dá ao homem razões ou ilusões de estabilidade" (BACHELARD, 2008, p. 36). Esse filósofo destaca ainda que a casa comporta os semas /verticalidade/ e /centralidade/. A verticalidade decorre da polaridade / porão versus sótão/ e a centralidade da oposição /dentro versus fora/. Para os gregos, o espaço interior tem conotação feminina. Nele, a mulher está em seu domínio. O espaço exterior tem conotação masculina, já que o movimento do homem é centrífugo: é quem sai para a guerra e para a caça. Toda a ação do conto ocorre quando os maridos saem e os atores Ema e Bárbara permanecem no espaço da casa.

Para Greimas e Courtés (2012), a espacialização é um dos componentes da discursivização, ou seja, ela é um dos procedimentos pelos quais se fazem emergir as estruturas semióticas mais profundas. A espacialização permite que se inscrevam no discurso os programas narrativos, por meio da localização, que é a construção pelo sistema de debreagem de um esquema de referências que permite situar no espaço programas narrativos. Dessa forma, pelos mecanismos de embreagem e debreagem, vamos ter os pontos zero para a instalação de uma topologia tridimensional do discurso, que compreende os eixos verticalidade, horizontalidade e prospectividade.

A semiótica faz referência ainda à programação espacial, procedimento que, após a localização dos programas narrativos, permite o encadeamento sintagmático desses programas, correlacionando os sujeitos e seus programas narrativos com os espaços segmentados, no caso do conto objeto deste artigo, a sala e o quarto.

\section{SegmentaÇÃo do CONTO}

Para analisar a articulação semântica entre espaços e valores, segmentamos o conto, não com base em elementos do plano da expressão, parágrafos, estrofes, versos, formas que o enunciador utiliza para organizar seu discurso, mas em função de disjunções espaciais, temporais, actoriais. Dividimos o conto em três segmentos:

$1^{0}$ segmento: do início até "No momento em que Ema depositava o refresco na mesa, ouviu-se um estalo";

$2^{\circ}$ segmento: de "Porcaria, meu sutiã arrebentou" até "Até amanhã";

$3^{\circ}$ segmento: de "Ema examinou atentamente a sala, a conferir, pela última vez, a arrumação geral" até o final.

O primeiro corresponde aos temas da mulher dona de casa e da dominação da mulher e tem por espaço a sala. O segundo corresponde aos temas da intimidade, da erotização e da homossexualidade. O terceiro corresponde à separação das amigas e ao percurso do destinador-julgador, em que esse sanciona positi- 
vamente o sujeito da ação. Os temas da liberdade e da amizade estão diluídos por todo o conto.

No primeiro segmento, a conversação gira em torno da vida doméstica (filhos, empregada, marido, arrumação da casa). Nesse momento, a relação entre os atores é estereotipada, não havendo espaço para a intimidade. O comportamento de Ema é de uma mulher que quer manter a sala, que é o espelho da casa, sempre arrumada (tema da mulher dona de casa). Tal comportamento é até mesmo obsessivo, chegando a chamar a atenção da amiga. Nesse segmento, centrado no esquema narrativo do sujeito da ação, figurativizado no ator Ema, temos o tema da liberdade, valor do qual o sujeito está em disjunção.

A quebra do fecho do sutiã de Ema acarreta uma mudança do tema da conversação, que agora passa a girar sobre o tamanho dos seios (tema da erotização). Com isso, a relação entre Ema e Bárbara, até então marcada pelo convencionalismo das relações sociais, passa a dar lugar a uma relação marcada pelos valores da intimidade e da aproximação física das duas mulheres ("Você acha que eu tenho seio demais?"), que vai desencadear a mudança espacial da sala para o quarto (do / baixo/ para o /alto/), onde as amigas se despem, ocorrendo a tonificação do valor intimidade. O espaço da intimidade faz que o desejo homossexual que uma tem pela outra se manifeste ("É muito bonita - Ema reconheceu. Cintura fina, pele sedosa, busto rosado e um dorso infantil"; "Carinhosa, Ema acariciou as costas da amiga, que sentiu um arrepio"). Há em seguida uma desaceleração com a volta dos sujeitos à sala, num movimento que vai do /alto/ para o /baixo/. Nesse segmento, há a negação do valor dominação e a afirmação do valor liberdade.

No último segmento, Bárbara executa um movimento direcional do englobado (a casa) para o englobante (a rua), movimento contrário executado por ela antes do início da narrativa. Em termos da categoria/exterioridade versus interioridade/, o movimento de Bárbara é do exterior para o interior e deste para o exterior novamente. Esses deslocamentos dos sujeitos do /exterior/ para o / interior/, do / baixo/ para o /alto/ e os seus contrários não apenas dinamizam a narrativa, como também são constitutivos do sentido, na medida em que os espaços são revestimentos figurativos de temas.

\section{UMA ANÁLISE SEMIÓTICA DE "INTIMIDADE"}

Como afirmamos, nossa análise repousa fundamentalmente na espacialização. No entanto, para que os procedimentos de espacialização e de programação espacial do texto fiquem mais claros, julgamos necessário tecer, em rápidas pinceladas, algumas considerações sobre o percurso gerativo do sentido e sobre o esquema narrativo.

\section{O percurso gerativo do sentido}

No nivel fundamental, "Intimidade" articula-se em torno da oposição semântica /liberdade vs. dominação/. Do ponto de vista da sintaxe fundamental, temos a negação da dominação (valor disfórico) e a afirmação da liberdade (valor eufórico), que corresponde à passagem do tenso para o distenso. 


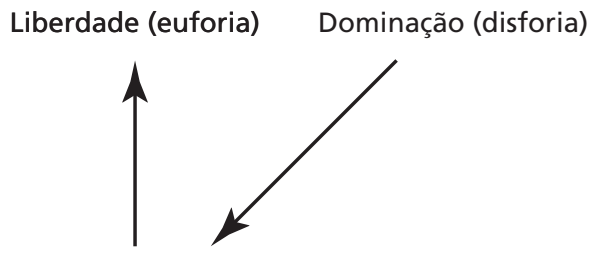

Não liberdade

Liberdade implica um / poder fazer/ e a dominação um / não poder fazer/. No nivel narrativo, o / poder fazer/ (liberdade) é assumido pelo sujeito da ação e se transforma em valor ideológico. Acompanharemos, em nossa análise, particularmente o percurso do sujeito Ema, suas transformações, rompimentos de contratos e sua relação comunicativa como o destinador-manipulador.

Quanto ao nível discursivo, nos alongaremos um pouco mais, uma vez que a espacialização pertence a esse nivel. Comecemos pela sintaxe discursiva, que nos interessa mais de perto em decorrência da espacialização.

Um enunciador instala, por debreagem enunciva, um actante narrador de focalização onisciente, que tudo sabe a respeito dos atores e de suas emoções e da totalidade dos acontecimentos. Usamos aqui o termo focalização para designar a perspectiva de um narrador frente à diegese, isto é, daquilo que é capaz de narrar levando em conta o que vê qualitativa e quantitativamente. Esse narrador onisciente controla o conjunto da cena narrativa, conferindo ao texto um efeito de sentido de objetividade e afastamento da instância da enunciação. Ressaltamos que o narrador ocupa o mesmo espaço dos sujeitos, acompanhando-os em seus deslocamentos dentro da casa. Pelo mecanismo da debreagem interna, instalam-se dois actantes, figurativizados em Ema e Bárbara, duas amigas inseparáveis, muito parecidas fisicamente, que ficaram grávidas ao mesmo tempo e tiveram filhos no mesmo hospital (“'Imaginava que fossem irmãs', muitos diziam, o que sempre causava satisfação"), o que reforça a identidade entre ambas. Ema e Bárbara são interlocutoras no texto (debreagem interna). O discurso desses dois interlocutores é responsável pelos efeitos de sentido de realidade. No conto, o narrador adota, como percurso regente, o de Ema, a dona da casa que toma a iniciativa do jogo de sedução ("Vamos lá em cima. A gente se despe e compara"). Ao colocar Ema na função de regente, ela passa a ter maior importância narrativa que Bárbara, que passa ter papel secundário, ou seja, o discurso é organizado pelo narrador na perspectiva de Ema. Esclarecemos que o secundário refere-se à perspectiva que toma o narrador. O ator Bárbara, por exercer a função de destinador-manipulador, é a fonte dos valores que circulam e que são buscados pelo sujeito Ema, cuja competência modal para realizar a ação foi dada por Bárbara, que, ao dar a modalidade do querer a Ema, instala o sujeito virtual no texto, que seguirá um percurso narrativo até tornar-se um sujeito realizado.

O tempo do discurso não é concomitante à enunciação, que é presentificado quando o narrador põe em cena as interlocutoras. A narrativa começa in media res com as duas mulheres instaladas na sala da casa de Ema, já em plena conversação. 
O componente semântico do discurso trata da tematização e do revestimento figurativo dos temas. Em "Intimidade", além do tema da liberdade, desenvolvem-se outras leituras temáticas: 1. tema da dominação do homem pela mulher; 2 . tema da mulher dona de casa; 3 . tema da intimidade; 4 . tema da amizade; 5. tema da erotização; 6. tema da homossexualidade, que são concretizados em diferentes investimentos figurativos.

Quadro 1 - Figuras que revestem os temas liberdade e dominação

\begin{tabular}{|l|l|l|}
\hline Traço & liberdade & dominação \\
\hline Visual & arrumado & desarrumado \\
\hline Visual & despida & vestida \\
\hline Auditivo & falante & calada (múmia) \\
\hline Auditivo & silencioso & barulhento \\
\hline Espacial & fechado & aberto \\
\hline
\end{tabular}

Fonte: Elaborado pelos autores.

Esses traços se manifestam em diferentes figuras e diferentes leituras temáticas. Por exemplo: o traço visual se manifesta na sala desarrumada e no quarto arrumado (tema da mulher dona de casa) e nas mulheres despidas e vestidas (tema da erotização); o traço auditivo se manifesta na televisão ligada e a mulher calada (tema da dominação da mulher pelo homem); o traço espacial se manifesta nos ambientes da casa, a sala e o quarto (tema da intimidade).

Pretendemos nos alongar um pouco no tema da erotização, que no texto é recoberto por figuras como sutiã, passar a mão, busto, seio, lençóis, despir-se, pele, acariciar, arrepio, beijo, esfregar, produtoras de ilusão referencial, analisando a figura do sutiã e de seu fecho. O rompimento do fecho do sutiã é o momento crucial do conto, pois simboliza a passagem de estado de dominação, do fechamento, para um estado de liberdade, de abertura. Fecho é aquilo que prende, que impede que se abra, e o sutiã, para algumas mulheres, é visto como algo que oprime. Do ponto de vista da tensividade ${ }^{2}$, é a passagem de um estado de tensão para um de distensão. A quebra do fecho do sutiã provoca um estado de relaxamento, de afrouxamento, possibilitando a passagem de um estado marcado pela estereotipização dos comportamentos para um de intimidade. Do ponto de vista da aspectualização, o processo é pontual: o início coincide com o final (arrebentou). A passagem do estado de repressão para o de liberdade se dá de modo repentino e completo.

\section{O esquema narrativo}

Em "Intimidade", acompanhamos o percurso da ação do sujeito Ema. Pressupõe-se que o sujeito tenha a competência necessária para exercer essa ação.

2 Para Greimas e Courtés (2012), tensividade é a relação que o sema durativo e um processo contrai com o sema terminativo: isso produz o efeito de sentido de "tensão", "progressão". 
Esse sujeito é modalizado por um destinador-manipulador, fonte dos valores, que lhe propõe um contrato e manipula o destinatário-sujeito a aceitar esse contrato. O destinatário-sujeito só aceita o contrato porque os valores que lhe foram oferecidos são vantajosos (liberdade, intimidade), além de julgar o destinador confiável. Bárbara é um ator sincrético, pois é, ao mesmo tempo, destinador e objeto de desejo de Bárbara.

O conto inicia-se pelo percurso da manipulação. O ator Bárbara, que exerce a função de destinador-manipulador, manipula por intimidação o destinatário-sujeito Ema a aceitar o contrato pelo qual ela deve mudar do estado de dominação para o de liberdade, levando esse sujeito a um fazer. Para isso, atribui-lhe a competência modal do querer, transformando Ema num sujeito virtualizado. A fala de Bárbara, já no início do conto, "Só que já é noite" marca o início do percurso da manipulação por intimidação, que levará a uma mudança do papel temático exercido por Ema. Bárbara chama a atenção de Ema por ela não deixar de ser dona de casa, nem nos momentos de intimidade em que está só com a amiga. O efeito persuasivo do enunciado consiste no subentendido, na medida em que o dizer de Bárbara tem a função de um fazer-crer, pois revela que Ema passara o dia envolvida com as atividades de dona de casa. Ressaltamos o ethos positivo que Bárbara desfruta em relação a Ema, fato que favorece a manipulação ("Era tão bom ter uma amiga tão experiente"; "Bárbara muito mais sábia"; "Novamente a amiga tinha razão").

O sujeito Ema é modalizado também pelo saber e poder, tornando-se um sujeito atualizado. Ema, agora, quer, sabe e pode fazer. O percurso irá de um estado inicial de disjunção com o valor liberdade para um estado final de conjunção com esse valor.

A modalização não recai apenas no fazer, mas também no ser, ou seja, o sujeito de estado também pode ser modalizado pelo querer, pelo dever, pelo poder e pelo saber. O arranjo dessas modalidades do ser será responsável pelas paixões. Em "Intimidade", Ema quer-ser livre, o que configura o percurso passional do desejo, que se caracteriza pela aspiração em preencher um sentimento de falta ou incompletude.

O percurso do sujeito Ema é marcado por rompimento de contratos estabelecidos pelo destinador-social, como o de fidelidade ao marido e o de cumprir o papel de dona de casa, pois tem uma relação afetiva com Bárbara e, no final da narrativa, deixa de se preocupar com a arrumação da casa ("Reparou na bandeja esquecida sobre a mesa, mas não se incomodou”).

O caráter polêmico da narrativa pressupõe o percurso de um antissujeito, ou seja, aquele que dificulta o sujeito de entrar em conjunção com o objeto-valor buscado. No conto, o antissujeito é figurativizado no ator marido, que exerce um poder castrador sobre a mulher ("Se o marido estivesse em casa seria obrigada a assistir à televisão") ${ }^{3}$.

Chamamos a atenção, dada a sua relevância no conto, para o programa narrativo em que Ema investe em Bárbara os valores almejados, ou seja, Bárbara passa a ser casa sintática em que são investidos valores, como os de liberdade, os de identidade e os de sexualidade. A relação íntima de caráter erótico-sexual com a amiga permite a Ema entrar em conjunção com a liberdade, valor desejável.

O ator marido representa também a casa sintática em que são investidos valores sociais como dominação da mulher pelo homem, papel da mulher como dona de casa, heterossexualidade, fidelidade conjugal da mulher. Enfim, valores característicos de uma sociedade patriarcal e machista. 
O percurso do destinador-julgador coincide com o final do conto $\left(3^{\circ}\right.$ segmento) em que Ema representa esse actante, sancionando-se positivamente, na medida que cumpriu o contrato que fora proposto pelo destinador-manipulador, como se observa no trecho a seguir "Um sentimento de liberdade interior brotava naquele silêncio. Um sentimento místico, meio alvoroçado, de alguém que, de repente, descobrisse que sabe voar". Ema é agora um sujeito realizado.

\section{A espacialização em "Intimidade"}

Os espaços são explicitados no texto. O espaço englobante, a casa, é o espaço da vida familiar, da fidelidade, da heterossexualidade. Espaço que comporta, portanto, as oposições semânticas /marido vs. mulher/, /masculinidade vs. feminilidade/. O sema /masculinidade/ sobrepõe-se ao sema /feminilidade/, uma vez que marido corresponde a dominante e mulher a dominado: "Se o marido estivesse em casa seria obrigada a assistir à televisão, porque ele mal chegava, ia ligando o aparelho, ainda que soubesse que ela detestava sentar que nem múmia diante do aparelho".

O marco axial é a casa, um espaço experimentado em que os corpos se movimentam e que traduz a dinâmica das relações sensiveis dos seres. Esse espaço instala inicialmente no texto o sema / horizontalidade/. Temos aí a primeira oposição espacial /aqui vs. alhures/, que, do ponto de vista dos actantes, corresponde à oposição espacial /interioridade vs. exterioridade/. O aqui, espaço interior, é onde circulam os sujeitos e os objetos-valor e o alhures, espaço exterior, é ocupado pelos maridos. Sustentamos ainda que, entre os sujeitos semióticos, há um espaço regulado proxemicamente. Esse espaço compreende um maior ou menor afastamento entre os sujeitos em decorrência da intimidade (mais intimo $\rightarrow$ maior proximidade; menos intimo $\rightarrow$ menor proximidade). $\mathrm{Na}$ sala, a distância entre sujeitos é maior que no quarto. Quando uma situação (o rompimento da alça do sutiã) obriga a uma aproximação dos corpos, ocorre o deslocamento espacial, que, segundo Greimas (2014, p. 158),

[...] é geralmente interpretado como uma manifestação figurativa do desejo; em outras palavras, como a forma narrativa da modalidade do querer de que o sujeito está dotado. Na medida em que o deslocamento tem um objeto, pode-se defini-lo como uma busca.

No conto, o espaço casa se divide em dois, a sala e o quarto. Temos aí a categoria /englobante vs. englobado/, em que a casa é englobante em relação à sala e ao quarto, espaços englobados. Sala e quarto instauram o sema / verticalida$\mathrm{de} /$, que corresponde à categoria / baixo vs. alto/. Dentro da casa, o movimento dos actantes é da sala / baixo/, espaço enunciativo, para o quarto /alto/, espaço enuncivo, ("Vamos lá em cima. A gente se despe e compara - aproveitou a subida para recolher a desordem empilhada", grifos nossos).

Comecemos pela casa. Os semas correspondentes a ela no conto são: /interioridade/ e /englobante/. A casa é o espaço habitado, separado do mundo exterior por paredes, o que lhe confere o sentido de proteção e de barreira. A sala o espaço no interior da casa destinado a uso social. É o espelho da casa, o espaço da família e das relações sociais. O quarto é o espaço interior da casa desti- 
nado ao repouso e tem valor de intimidade. Quarto e sala correspondem às oposições semânticas /individual vs. social/, / privacidade vs. publicidade/ e / proximidade vs. afastamento/. No conto, a passagem da sala para o quarto é feita por uma escada, figura associada à ascensão, à valorização. A escada permite um movimento que vai do /baixo/ para o /alto/, do /social/ para o /individual/, do /afastamento/ para a / proximidade/.

$\mathrm{Na}$ oposição / alto vs. baixo/, o primeiro tem valor eufórico e o segundo, disfórico, como comprovam expressões da lingua comum: alto astral, subir na vida, estar em alta, estar por cima, superior, céu (positivos), que se opõem a baixo astral, descer na vida, estar em baixa, estar por baixo, inferior, inferno (negativos). Em sintese: no conto, o movimento dos sujeitos é do /social/ para o /individual/, do / revelado/ para o /escondido/. Portanto, aquilo que é íntimo e escondido é eufórico, aquilo que é exposto e revelado é disfórico. O conto, como se vê, é a afirmação dos valores intimidade, ascensão e valorização, que culminam com a liberdade conquistada.

Para entrar em conjunção com o objeto-valor intimidade, o sujeito deve realizar um percurso que implica necessariamente mudança de espaço. Ema manipula por sedução Bárbara para ter com ela uma relação investida pelo valor intimidade e, como esse valor só pode ser alcançado no espaço das relações privadas, é necessário que ocorra um deslocamento dos sujeitos, subindo da sala, espaço social, para o quarto, espaço da intimidade, do / baixo/ para o /alto/.

A sala, no conto, é um espaço tenso, portanto não propício à intimidade. Embora tenha posto as crianças para dormir a fim de poder ter um pouco mais de intimidade com a amiga, Ema não consegue relaxar, por estar sempre arrumando coisas que os meninos deixam espalhadas pela casa ("Ema agachou-se para recolher o quebra-cabeça esparramado pelo chão"; "descobriu um sapato sob a poltrona"; "empilhou os objetos no degrau da escada"), o que leva Bárbara a achar que a amiga sofre de algum transtorno obsessivo ("Bárbara pensou que a amiga talvez tivesse um pouco de neurose com arrumação"). Não há adaptação de Ema ao meio, portanto a sala é espaço disfórico, pois é o espaço da desarrumação, da desordem, o que incomoda Ema e, por extensão, Bárbara. Ema é oprimida por querer manter a sala sempre arrumada, vale dizer, na sala ela se comporta como a mulher responsável por manter a casa em ordem e funcionando (papel temático da dona de casa). É o espaço em que a dona de casa se manifesta com maior intensidade, espaço das relações tensas. A sala se opõe ao quarto, espaço em ordem, com a cama arrumada com lindos lençóis novos. O quarto é, portanto, o espaço distenso, próprio para as relações afetivas dos sujeitos. Nele, sentem-se adaptados e relaxados; espaço eufórico, portanto.

No conto, como defendemos, privacidade não é apenas um estado dos sujeitos, mas um lugar em que os sujeitos conseguem usufruir plenamente desse estado, sobretudo quando se dá à intimidade o valor de contato íntimo de natureza erótico-sexual, já que as coerções sociais agem no sentido de impedir que relações de natureza erótica ocorram no espaço não privado.

\section{CONSIDERAÇÕES FINAIS}

A narrativa como comunicação de valores ou transferência de objetos entre sujeitos pressupõe a existência de um espaço. O conto revela que o sujeito semiótico cria dentro de um espaço socializado um espaço alternativo em que são 
possiveis as relações de intimidade. Dedicamos especial atenção à categoria espaço a fim de demonstrar como em "Intimidade" ela é constitutiva do sentido e não apenas cenário onde sujeitos e objetos circulam. É no espaço que os sujeitos exercem sua competência e transformam seus estados pelo deslocamento. A programação espacial do conto se faz pela instalação de uma descontinuidade que cria dois espaços que se opõem: o quarto e a sala, que correspondem, respectivamente, aos semas /alto/, /proximidade/ e /baixo/, /afastamento/. O conto revela o percurso de um sujeito, figurativizado em Ema, modalizado por Bárbara, em busca da liberdade, por meio de programas narrativos de aquisição de valores. Um programa narrativo destaca-se: aquele que permite aos sujeitos entrar em conjunção com o valor intimidade, isso se realiza por meio do contato físico e ocorre no espaço privativo das relações íntimas, figurativizado no quarto. Antes que houvesse o deslocamento espacial dos atores, que se dá no eixo da /verticalidade/, de baixo para cima, a possibilidade de relação mais íntima não se concretizava porque seus percursos narrativos ocorriam no espaço das coerções de natureza social, a sala. Em decorrência do contrato proposto pelo destinador social, os sujeitos ficam presos às personagens que representam socialmente, o que implica que os desejos sejam reprimidos. O conto traz à tona o conflito que decorre entre as pulsões individuais e as coerções sociais.

Por último, mas não menos importante, registramos que essa é uma das muitas possibilidades de leitura do conto. Nossa leitura foi feita com base na espacialização, sob a perspectiva da categoria / superatividade vs. inferatividade/. Outras são possiveis, mesmo levando em conta a espacialização.

\section{Spatialization and meaning in "Intimidade" of Edla Van Steen: a semiotic ANALYSIS}

Abstract: This article discusses the spatial distribution in the short story "Intimidade", written by Edla Van Steen. The goal is to show that the spatial distribution is constitutive of meaning, to the extent that space is themed as a privileged locus of the intimacy of the subjects. The theoretical foundation is the discursive semiotics of the French line. As space puts on the scene the subject was adopted also the prospect of tensivity. The results show that the changes of the subject are related to spatial displacement and the topological change, in view of tensivity, leads to distension in that the subjects go from a tense space, dysphoric space to an untensioned and euphoric space.

Keywords: Spatial. Direction. Semiotics.

\section{REFERÊNCIAS}

BACHElARD, G. A poética do espaço. 2. ed. São Paulo: Martins Fontes, 2008. BARROS, D. L. P. de. Teoria do discurso: fundamentos semióticos. São Paulo: Atual, 1988.

BARROS, D. L. P. de. Teoria semiótica do texto. 4. ed. São Paulo: Ática, 2003. 
FIORIN, J. L. As astúcias da enunciação: as categorias de pessoa, espaço e tempo. 2. ed. São Paulo: Ática, 2001.

GREIMAS, A. J. Descrição e narratividade: a propósito de "O barbante" de Guy de Maupassant. In: GREIMAS, A. J. Sobre o sentido II: estudos semióticos. São Paulo: Nankin; Edusp, 2014. p. 147-166.

GREIMAS, A. J.; COURTÉS, J. Dicionário de semiótica. 2. ed. São Paulo: Contexto, 2012.

TATIT, L. Análise semiótica através das letras. São Paulo: Ateliê Editorial, 2001. VAN STEEN, E. Intimidade. In: MORICONI, I. (Org.). Os cem melhores contos brasileiros do século. Rio de Janeiro: Objetiva, 2001. p. 447-450.

\section{ANEXO}

\section{INTIMIDADE}

Para mim esta é a melhor hora do dia - Ema disse, voltando do quarto dos meninos. - Com as crianças na cama, a casa fica tão sossegada.

- Só que já é noite - a amiga corrigiu, sem tirar os olhos da revista.

Ema agachou-se para recolher o quebra-cabeça esparramado pelo chão.

- É força de expressão, sua boba. O dia acaba quando eu vou dormir, isto é, o dia tem vinte e quatro horas e a semana tem sete dias, não está certo? - descobriu um sapato sob a poltrona. Pegou-o e, quase deitada no tapete, procurou o par embaixo dos outros móveis. - Não sei por que a empregada não reúne essas coisas antes de ir se deitar - empilhou os objetos no degrau da escada. - Afinal, é paga para isso, não acha?

- Às vezes é útil a gente fechar os olhos e fingir que não está notando os defeitos. Ela é boa babá, o que é mais importante. Ema concordou. Era bom ter uma amiga tão experiente. Nem precisa ser da mesma idade - deixou-se cair no sofá - Bárbara, muito mais sábia. Examinou-a a ler: uma linha de luz dourada valorizava o perfil privilegiado. As duas eram tão inseparáveis quanto seus maridos, colegas de escritório. Até ter filhos juntas conseguiram, acreditasse quem quisesse. Tão gostoso, ambas no hospital. A semelhança física teria contribuído para o perfeito entendimento? "Imaginava que fossem irmãs", muitos diziam, o que sempre causava satisfação.

- O que está se passando nessa cabecinha? - Bárbara estranhou a amiga, só doente pararia quieta. Admirou-a: os cabelos soltos, caídos no rosto, escondiam os olhos cinza, azuis ou verdes, conforme o reflexo da roupa. De que cor estariam hoje? - inclinou-se - estão cinza.

Ema aprumou o corpo.

- Pensava que se nós morássemos numa casa grande, vocês e nós... 
Bárbara sorriu. Também ela uma vez tivera a ideia - pegou o isqueiro e acendeu dois cigarros, dando um a Ema, que agradeceu com o gesto habitual: aproximou o dedo indicador dos lábios e soltou um beijo no ar.

- As crianças brigariam o tempo todo.

Novamente a amiga tinha razão. Os filhos não se suportavam, discutiam por qualquer motivo, ciúme doentio de tudo. O que sombreava o relacionamento dos casais.

- Pelo menos podíamos morar mais perto, então.

Ema terminava o cigarro, que preguiça. Se o marido estivesse em casa seria obrigada a assistir à televisão, porque ele mal chegava, ia ligando o aparelho, ainda que soubesse que ela detestava sentar que nem múmia diante do aparelho - levantou-se, repelindo a lembrança. Preparou uma jarra de limonada. Por que todo aquele interesse de Bárbara na revista? Reformulou a pergunta em voz alta.

- Nada em especial. Uma pesquisa sobre o comportamento das crianças na escola, de como se modificam as personalidades longe dos pais.

No momento em que Ema depositava o refresco na mesa, ouviu-se um estalo.

- Porcaria, meu sutiã arrebentou.

- A alça?

- Deve ter sido o fecho - ergueu a blusa - veja.

Bárbara fez várias tentativas para fechá-lo.

- Não dá, quebrou pra valer.

Ema serviu a limonada. Depois, passou a mão pelo busto.

- Você acha que eu tenho seio demais?

- Claro que não. Os meus são maiores...

- Está brincando - Ema sorriu e bebeu o suco em goles curtos, ininterruptos.

- Duvida? Pode medir...

- De sutiã não vale - argumentou. - Vamos lá em cima. A gente se despe e compara - aproveitou a subida para recolher a desordem empilhada. Fazia questão de manter a casa impecável. Bárbara pensou que a amiga talvez tivesse um pouco de neurose com arrumação.

Ema acendeu a luz do quarto.

- Comprou lençóis novos?

- Mamãe mandou de presente. Chegaram ontem. Esqueci de contar. Não são lindos?

- São.

- A velha tem gosto - Ema disse, enquanto se despia em frente ao espelho. Bárbara imitou-a.

É muito bonita - Ema reconheceu. Cintura fina, pele sedosa, busto rosado e um dorso infantil. Porém, ela não perdia em atributos, igualmente favorecida pela sorte. Louras e esguias, seriam modelos fotográficos, o que entendessem, em se tratando de usar o corpo - não é, Bárbara?

- Decididamente perdi o campeonato. Em matéria de tamanho os seus seios são maiores do que os meus - a outra admitiu, confrontando.

Carinhosa, Ema acariciou as costas da amiga, que sentiu um arrepio.

- O que não significa nada, de acordo? - deu-lhe um beijo.

- Credo, Ema, suas mãos estão geladas e com este calor...

- É má circulação. 
- Coitadinha - Bárbara esfregou-as vigorosamente. - Você precisa fazer massagens e exercícios, assim - abria e fechava os dedos, esticando e contraindo na palma. - Experimente.

Eram tão raros os instantes de intimidade e tão bons. Conversaram sobre as crianças, os maridos, os filmes da semana. Davam-se maravilhosamente - Bárbara suspirou e se dirigiu à janela: viu telhados escuros e misteriosos. Ela adoraria ser invisivel para entrar em todas as casas e devassar aquelas vidas estranhas. Costumava diminuir a marcha do carro nos pontos de ônibus e tentar adivinhar segredos nos rostos vagos das filas. Isso acontecia nos seus dias de tristeza. Alguma coisa em algum lugar, que ela nem suspeitava o que fosse, provocava nela uma sensação de tristeza inexplicável. Igual à que sente agora. Uma tristeza delicada, de quem está de luto. Por quê?

- Que horas são? - Ema escovava o cabelo.

- Imagine, onze horas. Tenho que sair correndo.

- Que pena. Não sei por que fui pensar em hora. Fique mais um pouco.

- É tarde, Ema. Tchau. Não precisa descer.

- Ora, Bárbara... deixa disso - levou a amiga até o portão. - Boa noite, querida. Durma bem.

- Até amanhã.

Ema examinou atentamente a sala, a conferir, pela última vez, a arrumação geral. Reparou na bandeja esquecida sobre a mesa, mas não se incomodou. Queria um minutinho de... ela apreciava tanto a casa prestes a adormecer apagou as luzes. A noite estava clara, cor de madrugada pensou, sentando no sofá. Um sentimento de liberdade interior brotava naquele silêncio. Um sentimento místico, meio alvoroçado, de alguém que, de repente, descobrisse que sabe voar. Por quê?

Recebido em maio de 2016. Aprovado em setembro de 2016. 